\title{
The Effect of Betel Leaf Water Decoction on Perineal Wound Healing among Post Partum Women
}

\author{
Nursupma Oktavia Darulis ${ }^{1}$, Rini Kundaryanti ${ }^{2}$, Shinta Novelia ${ }^{3^{*}}$ \\ 1,2,3Department of Midwifery, Faculty of Health Science Universitas Nasional, Indonesia; \\ shinta.novelia@civitas.unas.ac.id (Corresponding Author)
}

\begin{tabular}{|c|c|}
\hline Article Info: & ABSTRACT \\
\hline Submitted: & The prevalence of maternity women with perineal injuries in Indonesia is $68 \%$ with an \\
\hline 30-08-2021 & average age of $25-39$ years, perineal injuries are the main cause of $40 \%$ of maternal \\
\hline Revised: & deaths in Indonesia. This study aimed to determine the effect of betel leaf water \\
\hline 02-10-2021 & decoction on post partum women perineal wound healing at the Independent Practice \\
\hline Accepted: & of midwife R. Agustina in West Bandung in 2021. This research used the Quasi \\
\hline $11-10-2021$ & $\begin{array}{l}\text { Experimental Design method, with the Post Only Control Group approach. The } \\
\text { population in this study were all postpartum women who had grade I and II perineal } \\
\text { injuries at PMB R. Agustina in July } 2021 \text { which consisted of } 30 \text { respondents. The } \\
\text { location of this research was carried out at the Independent Practice of the midwife R. } \\
\text { Agustina West Bandung in July 2021. The variables of this study were betel leaf boiled }\end{array}$ \\
\hline $\begin{array}{l}\text { DOI: } \\
\text { https://doi.org/10.53713/nhs.v1i2.64 }\end{array}$ & $\begin{array}{l}\text { water and perineal wounds. The research instrument was the REEDA Scale. The } \\
\text { results showed that the average perineal wound healing before intervention in the }\end{array}$ \\
\hline & $\begin{array}{l}\text { experimental group was } 10.60 \text { and after intervention was } 5.87 \text {, while the average } \\
\text { perineal wound healing before test was } 10.87 \text { and after the test was } 6.93 \text {. There were } \\
\text { differences in perineal wound healing between the experimental and control groups at } \\
\text { PMB R. Agustina West Bandung ( } p \text {-value }=0.012 \text { ). This intervention is expected to be }\end{array}$ \\
\hline (c) (i) () & $\begin{array}{l}\text { used by the community as a method in overcoming the problem of perineal wound } \\
\text { healing among post partum women. }\end{array}$ \\
\hline
\end{tabular}

This work is licensed under CC BY-SA License.

Keywords: post-partum women; perineal wound; betel leaf.

\section{INTRODUCTION}

In Asia, perineal injuries are also quite a problem in society, $50 \%$ of the world's perineal injuries occur in Asia. The prevalence of maternity women with perineal injuries in Indonesia in the $25-30$ year age group was $24 \%$, while the $32-39$ year old was $62 \%$. Perineal wounds are the cause of postpartum maternal bleeding. Postpartum hemorrhage was the main cause of $40 \%$ of maternal deaths in Indonesia (Sari \& Putri, 2017).

Perineal tears occur in almost all first deliveries and not infrequently also in subsequent deliveries. Perineal tears generally occur in the midline and can become extensive if the fetal head is born too quickly, the angle of the pubic arch is smaller than usual, the fetal head passes through the pelvic inlet with a larger size than the suboccipito-bregmatic circumferential. Perineal wound was an injury to the urogenital diaphragm and levator ani muscle, which occurs during normal delivery, or delivery with a device, can occur without injury to the perineal skin or the vagina, so it is not visible from the outside (Nurjanah, Puspitaningrum \& Ismawati, 2017).

One of the main causes of maternal death in developing countries is puerperal infections such as sepsis. Injury to the birth canal is one of the media for the development of germs so that it can be the cause of puerperal infection. This is due to the lack of maintaining cleanliness in birth canal injuries and the low endurance of the mother after giving birth (Prawirohardjo, 2016). The delay in wound healing is due to several problems including changes in vital signs caused by bleeding, infections such as skin redness, fever and pain, partial or complete rupture of sutures due to trauma and protrusion of internal organs to the outside due to the wound not fused immediately well (Hidayat, 2009).

Treatment for perineal wounds can be done by pharmacological and non-pharmacological methods. Pharmacological treatment is by giving antiseptic drugs. Antiseptic or antibiotic treatment for perineal wound care is currently likely to be avoided. Some antibiotics should be avoided during lactation, because the amount is very significant and risky. This is the reason for midwives who advise postpartum mothers to use betel leaf as a medicine that accelerates the healing of perineal wounds (Elisabet, 2017). 
Betel leaf in Latin known as Piper Betle is a native Indonesian plant that grows vines. Betel leaf is known to have a chemical content that acts as an antiseptic and antibacterial drug, besides that, betel leaf also contains chemicals as an anti-inflammatory agent that is good for use in mothers with wounds, especially in perineal wounds which can help accelerate the healing process of perineal wounds (Nurulhatam, 2016). Betel leaf is a plant that has a therapeutic effect. Betel leaf contains essential oils, hydroxykavicol, clavicle, cavibetol, allypyrokatekol, cineole, caryopyllene, cadinene, estragol, terpennea, sesquiterpene, phenylpropane, tennin, diastase, arecoline. The betel leaf ingredients, such as kavicol, essential oils, are anti-fungal and anti-bacterial. Among these ingredients, betel also has anti-biotics, arecoline is useful for stimulating the central nervous system to increase peristaltic movement so that blood circulation in the wound becomes smooth, oxygen becomes more abundant, thus affecting faster wound healing. Based on these effects, betel can be used as a wound treatment (Yuliaswati, 2018).

Based on the research results of Wanti \& Sitanggang (2017), 15 people who use boiled water betel leaf, the duration of perineal wound healing was 5 days, while people who did not use boiled betel leaf water, the duration of perineal wound healing was 11 people $>5$ days and 4 people 5 days. Based on the results of a preliminary study conducted by researchers at Midwife Private Clinic R.Agustina West Bandung, researchers obtained data for the last three months there were 60 clients who gave birth at Midwife Private Clinic R.Agustina, out out of 60 clients, 40 clients both primipara and multipara had perineal injuries with an episiotomy and 20 clients experienced a tear without an episiotomy in the second stage of labor. Some clients when asked if they know about how to speed up the healing of perineal wounds, the client said that he was only told that when cleaning the vulvar area he had to use cold water instead of warm water in order to minimize the loss of stitches in the perineal wound, but were not told how to treat the perineal wound so that get well soon.

\section{METHOD}

This experimental research method uses the Quasi Experimental Design method, with the Post Only Control Group approach. The population in this study were all postpartum mothers who had grade I and II perineal injuries at Midwife Private Clinic R. Agustina from May to July 2021 totaling 30 respondents. The location of this research was carried out at the Independent Practice of the R. Agustina Midwife, West Bandung in July 2021. The variables of this study were betel leaf boiled water and perineal wounds. The research instrument to measure wound healing was REEDA Scale Observation sheet. Data analysis used paired t-test statistical test and independent t-test test with a significant level of $p$-value $<0.05$.

\section{RESULT}

Table 1. The perineal wound healing before and after intervention in both group

\begin{tabular}{lccccc}
\hline \multicolumn{1}{c}{ Perineal wound } & Mean & SD & Min & Max & N \\
\hline Experiment group & & & & & \\
$\quad$ Before intervention & 10.60 & 1.242 & 9 & 13 & 15 \\
$\quad$ After intervention & 5.87 & 1.060 & 4 & 7 & 15 \\
\hline Control group & & & & & \\
$\quad$ Pre test & 10.87 & 1.302 & 9 & 13 & 15 \\
Post test & 6.93 & 1.100 & 5 & 8 & 15 \\
\hline
\end{tabular}

Based on table 1 above, it is known that the average perineal wound healing before intervention in the experimental group was 10.60 with a standard deviation of 1.242. Perineal wound healing after intervention in the experimental group was 5.87 with standard deviation was 1.060. Furthermore, average pre-test perineal wound healing in the control group was 10.87 with a standard deviation of 1.302 and the average post-test perineal wound healing in the control group was 6.93 with a standard deviation of 1.100 . 
Table 2. The differences of Perineal wound healing before and after intervention

\begin{tabular}{lccccc}
\hline Perineal wound & Mean & Std. Deviation & $\begin{array}{c}\text { Mean } \\
\text { difference }\end{array}$ & t-test & p-value \\
\hline $\begin{array}{l}\text { Experiment group } \\
\quad \text { Before }\end{array}$ & 10.60 & 1.242 & 4.733 & 30.882 & 0.000 \\
$\quad$ After & 5.87 & 1.060 & & & \\
\hline $\begin{array}{l}\text { Control group } \\
\quad \text { Pre test }\end{array}$ & 10.87 & 1.302 & 3.933 & 17.238 & 0.000 \\
$\quad$ Post test & 6.93 & 1.100 & & & \\
\hline
\end{tabular}

Based on table 2 above, the statistical test results obtained t-test $t$ table, $30,882>1,684$, $p$-value $=0.000(p$ value $<=0.05$ ) which means that there was significant difference of perineal wound healing before and after intervention in both group.

Table 3. The differences of perineal wound healing between experiment and control group after intervention

\begin{tabular}{|c|c|c|c|c|c|}
\hline Perineal wound & Mean & Std. Deviation & $\begin{array}{c}\text { Mean } \\
\text { difference }\end{array}$ & t-test & $p$-value \\
\hline Experiment group & 5.87 & 1.060 & \multirow{2}{*}{1.067} & \multirow{2}{*}{2.477} & \multirow{2}{*}{0.027} \\
\hline Control group & 6.93 & 1.100 & & & \\
\hline
\end{tabular}

Based on table 3 above, the statistical test results obtained $t$-test $>t$ table, 2,477> 1,684, $p$-value $=0.027$ ( $p$-value $<=0.05$ ) which means that there was a significant difference of perineal wound healing between the experimental and control group.

\section{DISCUSSION}

In this study, it was seen that the average perineal wound healing before intervention in the experimental group was 10.60. Perineal wound healing after the intervention in the experimental group was 5.87 with a standard deviation of 1.060. From the research of Kurniawati \& Ulfa (2015), the data obtained in the treatment group were most of the respondents $(62.5 \%)$ who recovered on the 5th day. The research of Rostika, Choirunissa \& Rifiana (2020), showed that the average healing time of perineal wounds after the use of red betel leaf boiled water (experimental group) was 5.80 days with a median of 5.00 days and a standard deviation of 1.506. The fastest is 3 days and the longest is 9 days. Harini's research (2019), that of the 20 women who were involved in the study, 10 people or about $50 \%$ of the women used betel leaf for wound healing.

The average pre-test perineal wound healing in the control group was 10.87 with a standard deviation value of 1.302. The average post-test perineal wound healing in the control group was 6.93 with a standard deviation of 1 . From the research of Kurniawati \& Ulfa (2015), the data obtained in the non-treatment group, most of the respondents (62.5\%) recovered on the 8th day. Research by Rostika, Choirunissa \& Rifiana (2020), in the control group the average perineal wound healing time was 7.80 days with a median of 8.00 days and a standard deviation of 1.014 . The fastest was 6 days and the longest was 10 days. Harini's research (2019) explained that of the 20 women who were involved in the study, 10 people or about $50 \%$ of the mothers used betadine type antiseptic for wound healing.

Based on the results of statistical test analysis, it was found that was a difference in perineal wound healing between the experimental and control groups. From the research of Kurniawati \& Ulfa (2015), the statistical results of the Mann Whitney U-Test show that there was a difference in the healing time of perineal wounds between groups using betel leaf and groups that do not use betel leaf. Rostika, Choirunissa \& Rifiana (2020) research, the results of statistical tests with independent t-test with $a=0.05$ obtained $p$ value $=0.001$ which means $p$ value $<0.05$, thus there was an effect of using boiled water of red betel leaf on time Perineal wound healing at Aster Clinic, Karawang Regency in 2020. Harini's research (2019) results of the t-test analysis obtained a t-count value (10.08) and a table value (2.20) that it can be interpreted that wound care with betel leaf is more effective than betadine for perineal wound healing in post-partum women.

The puerperium (puerperium) begins after the birth of the placenta until the reproductive organs recover as they were before pregnancy. And normally the puerperium lasts for about 6 weeks or 40 days (Elisabeth, 2015). Perineal wounds are injuries to the perineum due to a tear in the birth canal either due to rupture or an episiotomy during delivery of the fetus (Purwoastuti \& Walyani, 2015). According to Oxorn (2015), perineal tears are obstetric tears that occur in the 
perineal area due to the inability of the pelvic muscles and soft tissues to accommodate the birth of the fetus. Childbirth often causes injury to the birth canal. The injuries are usually mild but often extensive and dangerous injuries occur, so after delivery, the vulva and perineum should be examined.

Factors that cause perineal rupture include maternal factors consisting of parity, birth spacing, improper pushing method, and maternal age. Fetal factors consist of newborn weight and presentation. Vaginal delivery factors consist of forceps extraction, vacuum extraction, instrument trauma and episiotomy, then delivery support factors, namely inappropriate delivery leadership (Prawitasari, Yugistyowati \& Sari, 2015). Episiotomy is an incision in the perineum that causes the vaginal mucous membrane to cut, the blood membrane ring, the tissue in the rectovaginal septum, muscles and skin in front of the perineum (Purwoastuti \& Walyani, 2015). Perineal wound care can be done using pharmacological or non-pharmacological treatment. Non-pharmacological perineal wound care can be done in many ways, one of which is by using boiled water of betel leaf.

Betel leaf has chemical properties and chemical properties. Betel leaf contains essential oils consisting of hydroxy kavikol, cavibetol, estragol, eugenol, metileugenol, carvagol. One-third of the essential oil consists of phenol and most of it is kavikol which gives the smell of betel leaf cash and has five times the bacteria-killing power of ordinary phenol. Betel leaf contains saponins which refer to the formation of collagen, which is a structural protein that plays a role in the wound healing process, while other ingredients in betel leaf are chavicol, which is one of the components contained in betel leaf which functions as an antiseptic (Kurniarum \& Kurniawati, 2015). In addition, the content of betel leaf is useful for reducing bleeding in wounds, reducing swelling (Ellis, 2017). How to process betel leaves to be washed on wounds around the reproductive area or vagina is to boil 4 pieces of betel leaf using $400 \mathrm{ml}$ of water then bring to a boil, when it boils then the water is filtered and then cooled, then the boiled water of betel leaf can be used as washing in the wound area or around the genitals, do this treatment when bathing twice a day and during defecation (Damarini, Eliana, Mariati, 2012). Betel leaf is used to heal or stop bleeding, besides that, betel leaf is used for cebok medicine or cleaning the genital area of women with perineal wounds.

Treatment for perineal wounds can be done by pharmacological and non-pharmacological methods. With pharmacology, namely by giving antiseptic drugs. Antiseptic or antibiotic treatment for perineal wound care currently tends to be avoided. Some antibiotics should be avoided during lactation, because the amount is very significant and risky. This is the reason midwives advise postpartum mothers to use betel leaf as a drug that accelerates the healing of perineal wounds (Elisabet, 2017). According to Kurniarum \& Kurniawati (2015), betel leaf contains essential oils consisting of hydroxy kavikol, cavibetol, estragol, eugenol, metileugenol, and carvagol. One-third of the essential oil consists of phenol and most of it is kavikol which gives the smell of betel leaf cash and has five times the bacteria-killing power of ordinary phenol. Betel leaf contains saponins which refer to the formation of collagen, which is a structural protein that plays a role in the wound healing process, while other ingredients in betel leaf are chavicol, one of the components contained in betel leaf which functions as an antiseptic.

According to researchers, the use of betel leaf twice a day is intended so that the perineal wound is more often in contact with betel leaf boiled water. Betel leaf contains essential oils consisting of bethephenol, chavicol, sesculterpene, hidriksivaikal, cavibetol, estrogen, eugenol, and karvarool Where the biochemical substances in betel leaf (Piperbetlelinn.) have the power to kill germs and fungi, are also antioxidants that accelerate the wound healing process. Parity also affects postpartum women in performing perineal care. Experience is the best teacher. Because experience is a source of knowledge. If someone has given birth to a second child and so on, they can generally carry out perineal care well because they have gained experience and information on previous child births. In addition, factors that influence the healing of perineal wounds include tradition. Tradition greatly influences wound healing, in Indonesia, ancestral heritage ingredients for postpartum care are still widely used by modern society. Mother's knowledge about postpartum care also greatly determines the length of perineal wound healing. If the mother's knowledge is lacking, especially about hygiene issues, the wound healing will take a long time. This supports the mother's ability to provide infrastructure for perineal care, for example the mother's ability to provide antiseptic.

According to Primadona \& Susilowati (2015), the wound healing process has three phases, namely the Inflammatory Phase (inflammatory process), the wound healing process that lasts from the first 24 hours to 48 hours. The two stages in this phase are hemostasis (clotting) and phagocytosis. When the wound healing process takes place, the blood clot will release a chemical that will cause inflammation, so that when the blood starts to stop around the wound, swelling and redness will be seen. Ploriferation phase (the process of building new tissue), which lasts from 48 hours to 5 days. This stage is the stage of scar tissue formation after the wound. At this stage, collagen begins to grow in the wound. Collagen is a protein fiber that provides strength and an elastic texture on the skin so that the wound shrinks and closes. Maturation Phase (Stage of maturation or strengthening of tissue) lasts from day 5 until the wound heals completely. The tissue maturation process can take months or even years. In the process of wound healing, you should 
get good care, if you don't get good care, it will cause a pathological condition. This is slightly different from the opinion of Prawirohardjo (2006) that the average birth canal wound will heal in 6 to 7 days if there is no infection.

At the time of the study, all respondents did not experience signs of infection, thus making the researchers look for other factors that cause the perineal wound to heal slowly. According to researchers with many parity conditions of skin and muscle tissue, the return process takes a long time, thus prolonging wound healing time. Nutrition that is not in accordance with balanced nutrition. Researchers have tried to control nutritional intake by means of counseling and counseling, but researchers do not guarantee whether the respondents apply it seriously. This is in line with the theory which states that nutritional factors, especially protein, will greatly affect the wound healing process in the perineum because tissue replacement really needs protein. Lack of personal hygiene. Researchers have tried to control personal hygiene by way of counseling. Further research is needed to control the confounding variables. The midwifes need to implement this intervention to improve perineal wound healing.

\section{CONCLUSION}

The results show that was a difference in perineal wound healing between the experimental and control groups at Midwife Private Clinic R. Agustina, West Bandung. It can be concluded that betel leaf decoction water can be used as an alternative to accelerate the healing of perineal wounds among post-partum women. In addition, there is a need for the role of health workers, especially midwives, in providing education to post-partum women to improve personal hygiene as an effort to heal perineal wounds and prevent the infections. Thus, it would increase maternal health.

\section{ACKNOWLEDGEMENT}

The author would like to thank the National University for the support and partial funding that has been given for this research so that it can be carried out.

\section{REFERENCES}

Damarini, S., Eliana, E., \& Mariati, M. (2013). Efektivitas sirih merah dalam perawatan luka perineum di Bidan praktik mandiri. Kesmas: Jurnal Kesehatan Masyarakat Nasional (National Public Health Journal), 8(1), 39-44.

Elisabet., (2017). Kehamilan, Persalinan dan Nifas. Jakarta: EGC.

Ellis, L. (2017). Super Plants For Super Health: Hidup Sehat Dengan Memanfaatkan Tumbuhan Berkhasiat Obat Di Indonesia. Yogyakarta: PT Tiga Serangkai.

Harini, R., (2019), Upaya Percepatan Penyembuhan Luka Perineum Pada Ibu Post Partum Dengan Antiseptik Daun Sirih Di Puskesmas Wagir Kabupaten Malang. Jurnal Kesehatan Mesencephalon, 5(2).

Hidayat, M. (2009). Keterampilan Dasar Praktik Klinik Untuk Kebidanan. Jakarta: Salemba Medika.

Kurniarum, A., \& Kurniawati, A., (2015), Keefektifan Penyembuhan Luka Perineum Pada Ibu Nifas Menggunakan Daun Sirih. Interest: Jurnal Terpadu IImu Kesehatan. Volume 4 HIm 82196.

Kurniawati, S. L. C., \& Ulfa, M. (2015). Perbedaan Penggunaan Daun Sirih terhadap Waktu Penyembuhan Luka Perineum. Jurnal Ners dan Kebidanan (Journal of Ners and Midwifery), 2(3), 227-231

Nurulhatam, E. (2016). Keefektifan Penyembuhan Luka Perineum Dengan Menggunakan Rebusan Daun Sirih Merah Dan Mengkomsumsi Telur Rebus Pada Ibu Nifas Ny. K Umur 21 Tahun Di Bpm Sri Sudarsih Kebumen. Doctoral dissertation, STIKES Muhammadiyah Gombong.

Nurjanah, S., Puspitaningrum, D., \& Ismawati, R. (2017, October). Hubungan Karakteristik dengan Perilaku Ibu Nifas dalam Pencegahan Infeksi Luka Perineum di RS Roemani Muhammadiyah Semarang. In Prosiding Seminar Nasional \& Internasional (Vol. 1, No. 1).

Oxorn, W. (2015). IImu Kebidanan Patologi dan Fisiologi K ebidanan. Yogyakarta: C.V. Andi offset.

Prawirohardjo, S. (2006). Buku Acuan Nasional Pelayanan Kesehatan Maternal dan Neonatal. Jakarta: Yayasan Bina Pustaka.

Prawirohardjo, S. (2016). IImu Kebidanan. Jakarta: Yayasan Bina Pustaka.

Prawitasari, E., Yugistyowati, A., \& Sari, D. K. (2015). Penyebab Terjadinya Ruptur Perineum pada Persalinan Normal di RSUD Muntilan Kabupaten Magelang. Jurnal Ners dan Kebidanan Indonesia, 3(2), 77-81.

Primadona, P., \& Susilowati, D. (2015). Penyembuhan luka perineum fase proliferasi pada ibu nifas. Profesi (Profesional Islam). Media Publikasi Penelitian, 13(1).

Purwoastuti., \& Walyani. (2015). IImu Obstetric dan Ginekologi Sosial Untuk Kebidanan. Yogyakarta: Pustaka Baru press.

Rostika, T., Choirunissa, R., \& Rifiana, A. J. (2020). Pemberian Penggunaan Air Rebusan Daun Sirih Merah Terhadap Waktu Penyembuhan Luka Perineum Derajat I Dan II di Klinik Aster Kabupaten Karawang. Jurnal IImiah Kesehatan.

Sari, D. U., \& Putri, H. A. (2017). Hubungan senam hamil dengan kejadian ruptur perineum pada persalinan normal di rsu pku muhammadiyah bantul (Doctoral dissertation, Universitas' Aisyiyah Yogyakarta). 
Wanti, D., \& Sitanggang, T. W. (2018). Pengaruh Penggunaan Rebusan Air Daun Sirih Terhadap Lama Penyembuhan Luka Perineum Pada Ibu Postpartum Di Rs. Sariningsih Tahun 2017. Jurnal Kesehatan STIKes IMC Bintaro, 2(2), 169-169.

Yuliaswati, E. (2018). Upaya Mempercepat Penyembuhan Luka Perineum Melalui Penggunaan Air Rebusan Sirih Hijau. IJMSIndonesian Journal on Medical Science, 5(1). 